\title{
2D Electrical Imaging Surveys for Leachate Plume Migration at an Old Dump Site in Ibadan South Western Nigeria: A Case Study
}

\author{
Dare Omolayo ${ }^{1}$ and Fatoba Julius Tope ${ }^{2}$ \\ ${ }^{1}$ Dasamol Georesource Company, Lagos, Nigeria \\ ${ }^{2}$ Department of Earth Sciences, Olabisi Onabanjo University, Ago Iwoye, Nigeria \\ Correspondence should be addressed to Dare Omolayo; dasamol@yahoo.com
}

Received 14 October 2013; Revised 10 February 2014; Accepted 12 February 2014; Published 26 March 2014

Academic Editor: Robert Tenzer

Copyright (C) 2014 D. Omolayo and F. J. Tope. This is an open access article distributed under the Creative Commons Attribution License, which permits unrestricted use, distribution, and reproduction in any medium, provided the original work is properly cited.

\begin{abstract}
The site surveyed is along a popular ring road in Ibadan. It is an old dump site which had been closed over a long period of time. Development into industrial and residential house schemes had crowded around the site. This development resulted in the exploitation of groundwater within the thick regolith that characterize the area. The investigation was carried out to ascertain leachate plume generation and migration and its impact on the surrounding soil and the groundwater. 2D electrical resistivity imaging using Wenner array was used to delineate the plume and probable trend of migration. The method involves the injection of low frequency DC current into the subsurface and measuring the potential difference set up by another pair of electrodes called potential electrodes. All the traverses show areas of very low resistivity values ranging between $4 \mathrm{ohm}-\mathrm{m}$ and $13.8 \mathrm{ohm}-\mathrm{m}$; in addition to this, the water samples collected from hand dug wells that surround the dump site show high total dissolved solids (TDS) with an average value of $2033 \mathrm{mg} / \mathrm{L}$, high conductivity with an average value of $2868 \mathrm{mg} / \mathrm{L}$, and high nitrate value (63 mg/L); these values are above the World Health Organization (WHO) permissible values. This poses a health challenge to the residents living around this site.
\end{abstract}

\section{Introduction}

Closed dumpsites and landfills dotted some urban cities in Nigeria and had been posing challenges to groundwater purity in the country $[1,2]$. The rural urban migration as a result of economic activities had caused these urban cities to keep increasing in population with attendant increase in generation of wastes. Further expansion had forced some of these dumpsites to be abandoned and, in most cases, they are not properly closed and contained using geomembranes. These wastes may contain toxic substances and as they are decomposed or biodegraded, with the presence of infiltrating water, organic liquid effluents known as leachate can be produced and pollute groundwater with time as they migrate. According to Rosqvist et al. [3], the pollutant load to the environment from a landfill or dumpsite is dependent on the quantity and the quality of the water that percolates through the landfill and reaches the surroundings. Ibadan lies within the tropics where rainfall is abundant (annual average rainfall is $1280 \mathrm{~mm}$ according to Olaniran [4]); therefore, we expect the contaminant load to be high for this area. Leachate plumes normally have low resistivity values because of high ion concentration [3]; this property makes the electrical resistivity method very suitable to map leachate plumes and it has been deployed in many parts of the world $[1,5-8]$. It has the ability to delineate areas of leachate generation, migration, and the area extent. The area is as shown in Figure 1.

1.1. Physiography, Climate, and Geologic Setting. The area investigated is undulating and slopes towards the east and north that ends up in a valley created by Oluyole River and this actually influence the groundwater flow paths, which we believe determines the migration path of the leachate which is also towards the east and north. Ibadan lies within the Basement Complex Rocks of southwestern Nigeria; the 


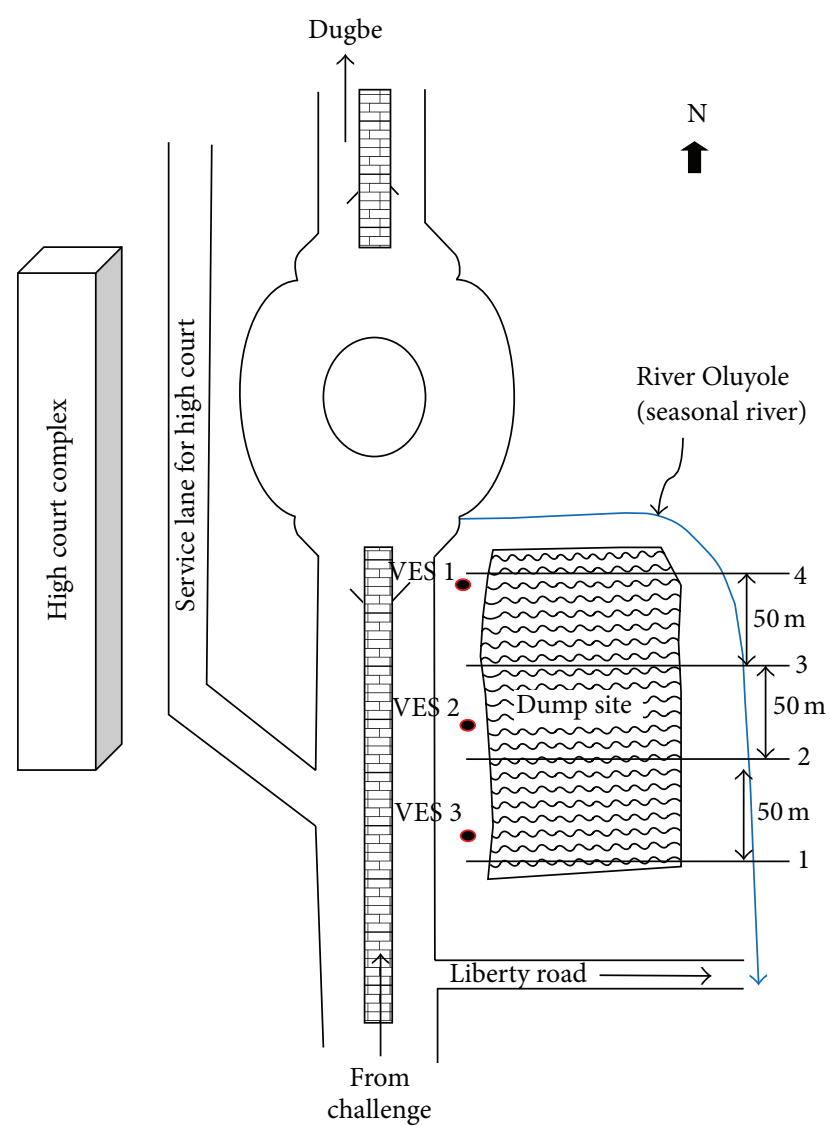

FIgURE 1: The sketch map of the area investigated (not to scale).

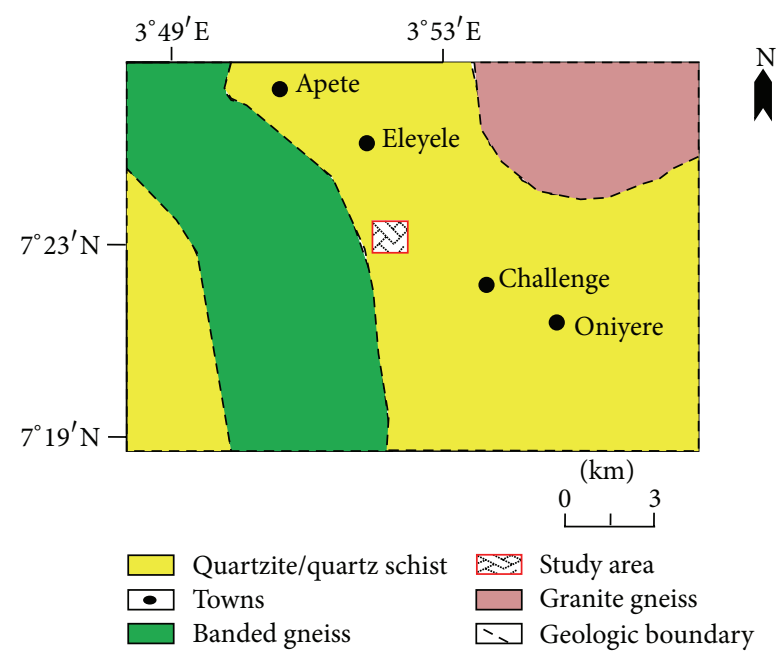

FIGURE 2: Geological map of Ibadan showing the study area (adapted from [12]).

dominant rock types in the area are the quartzite and the quartz schist. The weathering product is mostly clay as seen from the dugouts. Figure 2 is an adapted geological map of part of Ibadan showing the investigated area. Ibadan lies within the tropics; it has two main seasons: the dry and the wet season. Most rainfall (wet season) is seen between April and October, while the dry periods are from December to March. The annual average rainfall is $1280 \mathrm{~mm}$ [4].

\section{Methodology}

Geoelectrical resistivity survey is a common tool used for geotechnical and environmental surveys [9]. The electrical resistivity method is based on measurements of the potential distribution using two potential electrodes arising when electric current is transmitted into earth materials through two current electrodes. There is always a resistivity contrast between leachate plumes and the surrounding rocks according to [10]. Leachate plumes from municipal dumpsite are generally associated with high ion concentrations and, hence, low resistivity values. This makes geoelectric imaging relevant in the mapping of leachate plumes, its concentration, and migration.

The leachate plume contamination of the groundwater aquifer system and soil at the site investigated was delineated using $2 \mathrm{D}$ resistivity imaging methods and we try to constraint this method by carrying out a $1 \mathrm{D}$ resistivity investigation in the area using the Vertical Electrical Sounding (VES) technique. This enables us to know the resistivity distribution with depth in the area.

The equipment used is the MiniRes resistivity meter and the electrode configuration adopted is Schlumberger array for the 1D survey while the Wenner- $\alpha$ linear array was used for the $2 \mathrm{D}$ investigation. The VES data was acquired in the area away from the dumpsite so that there will be no influence from the leachate on the resistivity values. On the other hand, four (4) parallel profiles (1-4) were ran with inter profile spacing of $50 \mathrm{~m}$ from the beginning of the landfill towards the north for the 2D data (Figure 1). Measurements were made at sequences of increasing offset distance ( $a$-spacing) along the profile lines ranging from $2 \mathrm{~m}$ to $30 \mathrm{~m}$. The electrodes were moved from one end of the line to the other in a lip frog manner to achieve continuous horizontal resolution of the subsurface.

Finally, a record of the variation of the apparent resistivity of the subsurface with depth for each test line was obtained. This investigation was carried out during the dry season by which time the water table was at its deepest level and its influence reduced.

2.1. Data Processing and Presentation of Results. The 1D data was interpreted quantitatively using the partial curve matching method [11] followed by computer iteration using WinResist software package.

The measured 2D resistivity imaging data were processed using the DIPPRO inversion software. This program automatically subdivide the subsurface into a number of blocks and then uses a least-squares inversion scheme to determine the appropriate resistivity values for each block so that the calculated apparent resistivity values agree with the measured apparent resistivity values from the field survey. In anticipation of high resistivity contrast between the leachate plume and the surrounding rocks and soils, a low number of iterations were used; this, according to Olayinka and 


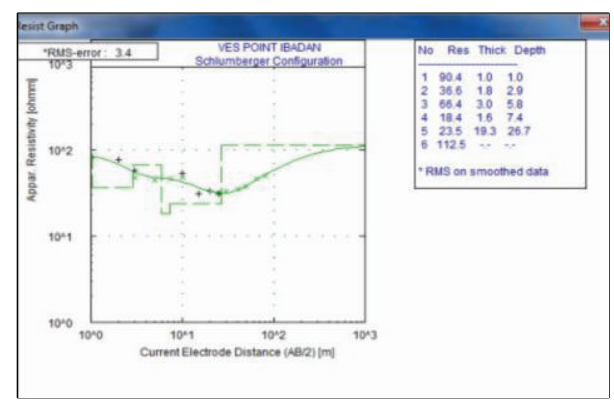

FIGURE 3: A typical 1D Schlumberger depth sounding curve gotten from the waste dump site, Ibadan.

TABLE 1

\begin{tabular}{lccc}
\hline Layer number & Resistivity & Depth to base & Lithology \\
\hline 1 & $90.4 \Omega-\mathrm{m}$ & $1.0 \mathrm{~m}$ & Clay \\
2 & $36.6 \Omega-\mathrm{m}$ & $1.8 \mathrm{~m}$ & Clay \\
3 & $66.4 \Omega-\mathrm{m}$ & $3.0 \mathrm{~m}$ & Clay \\
4 & $18.4 \Omega-\mathrm{m}$ & $1.6 \mathrm{~m}$ & $\begin{array}{c}\text { Clayey } \\
\text { weathered basement } \\
5\end{array}$ \\
& $23.5 \Omega-\mathrm{m}$ & $19.3 \mathrm{~m}$ & $\begin{array}{c}\text { Clayey } \\
\text { weathered basement } \\
6\end{array}$ \\
& $112.5 \Omega-\mathrm{m}$ & - & $\begin{array}{c}\text { Fractured/partially } \\
\text { weathered basement }\end{array}$ \\
\hline
\end{tabular}

Yaramanci [12], will reduce the number of misfit between the inverted model and the geologic model. The results are displayed as inverted model resistivity sections versus depth of the subsurface along the four profiles (Figures 4(a)-4(d)). The pseudo sections, consistently, show similar structures with variation on the detail level with depth and were visually inspected to delineate areas of anomalously low resistivity relating to leachate plume formation and migration; these zones were tagged high impact zones.

\section{Results and Discussion}

The typical result of $1 \mathrm{D}$ resistivity survey is as shown in Figure 3. They are QH type curves.

The point sounded is underlain by six layers; Table 1 shows the resistivity value and the corresponding lithology.

Table 1 shows that the area is underlain majorly by clay materials.

The result from the $2 \mathrm{D}$ resistivity survey is divided into profiles.

Profile 1. This is at the southern edge of the dumpsite and runs in an east-west direction (Figure 4(a)). Three zones were delineated beneath this profile.

Zone 1 is a very low resistivity zone (blue colour) with resistivity value ranging from $5.5 \Omega-\mathrm{m}$ to $11 \Omega-\mathrm{m}$. This zone is interpreted to be the dumped waste and the generated leachate plume cum the impacted soil. It starts from the surface to depths ranging between $2 \mathrm{~m}$ and $6 \mathrm{~m}$ towards the east between stations 5 and 25 . The low resistivity end of
TABLE 2

\begin{tabular}{lcc}
\hline Zone & $\begin{array}{c}\text { Resistivity value range } \\
(\mathrm{ohm}-\mathrm{m})\end{array}$ & Impact range \\
\hline 1 & $3.4 \Omega$-m to $11 \Omega-\mathrm{m}$ & High impact zone \\
2 & $25 \Omega$-m and $35 \Omega-\mathrm{m}$ & Low impact zone \\
3 & $>35 \Omega-\mathrm{m}$ & No impact zone \\
\hline
\end{tabular}

this spectrum indicates the real contaminant leachate plume, while the relatively high resistivity value is believed to be the migrating plume contaminating the surrounding soil. This zone is classified as high impact zone.

Zone 2 is a zone of moderately low resistivity values ranging between $11.3 \Omega-\mathrm{m}$ and $17.6 \Omega-\mathrm{m}$. This resistivity value range is a little bit lower than the resistivity of the clayey weathered zone got for the area. Hence, it is assumed that this zone had been impacted by the migrating leachate; it reaches up to $20 \mathrm{~m}$ at its deepest point which occurs at station 25 , this zone is classified as impacted zone. The preponderance of this zone in the eastern section lays credence to the fact that the leachate is migrating towards the east.

The third zone is the zone with resistivity value varying between $18 \Omega-\mathrm{m}$ and $181 \Omega-\mathrm{m}$; the lower resistivity value spectrum corresponds to the weathered basement resistivity value gotten from the $1 \mathrm{D}$ survey. This zone dominated the western portion of the profile especially the higher resistivity values. The zone is classified as no impact zone.

Profile 2. This profile is $50 \mathrm{~m}$ away from profile 1 towards the north of the dumpsite and also runs in an east-west direction (Figure 4(b)). Three zones were also delineated beneath this profile.

The first zone is a zone of very low resistivity values (3.4 $\Omega-\mathrm{m}$ to $11 \Omega-\mathrm{m}$ ). Two of such zones were identified; the first one lies between stations 8 and 17. It is shallower under station 8 and progressively increases in depth towards station 17 (the depth range is between $1 \mathrm{~m}$ and $6 \mathrm{~m}$ ). The second occurrence is between stations 20 and 32. It starts at the surface between stations 20 and 24, while it occurs at a relatively deeper depth between stations 25 and 32 . The zone is very pronounced under this profile and reaches up to $20 \mathrm{~m}$ towards the eastern section. This is the contaminant leachate plume mixed with decomposing waste and had impacted the surrounding soil; this zone is classified as very high impact zone.

The second zone is a zone of moderately low resistivity values ranging between $13 \Omega-\mathrm{m}$ and $25 \Omega-\mathrm{m}$. It occurs to the western section of the profile with depths ranging between $2 \mathrm{~m}$ under stations 1 to $20 \mathrm{~m}$ under station 22 ; this zone is classified as high impact zone. The third zone is the zone with resistivity value varying between $25 \Omega$-m and $35 \Omega$-m; the zone is classified as a low impact zone implying that the leachate contaminant is just trying to approach this zone; hence, its concentration within this zone is very low.

The fourth zone is classified as a zone of no impact. The zone is towards the west as well, where the resistivity values of this zone are generally greater than $35 \Omega-\mathrm{m}$; this value is 


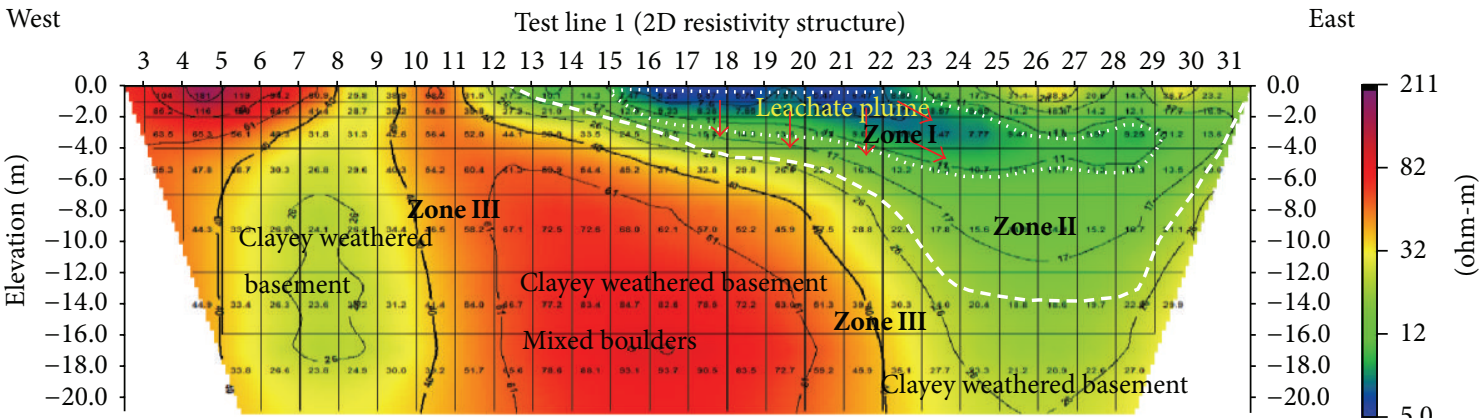

(a)

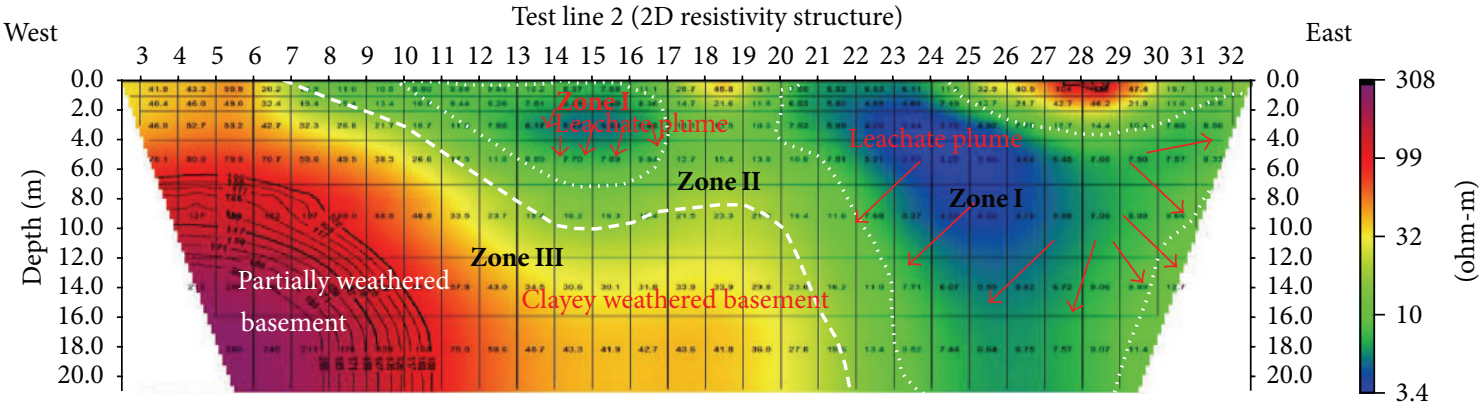

(b)

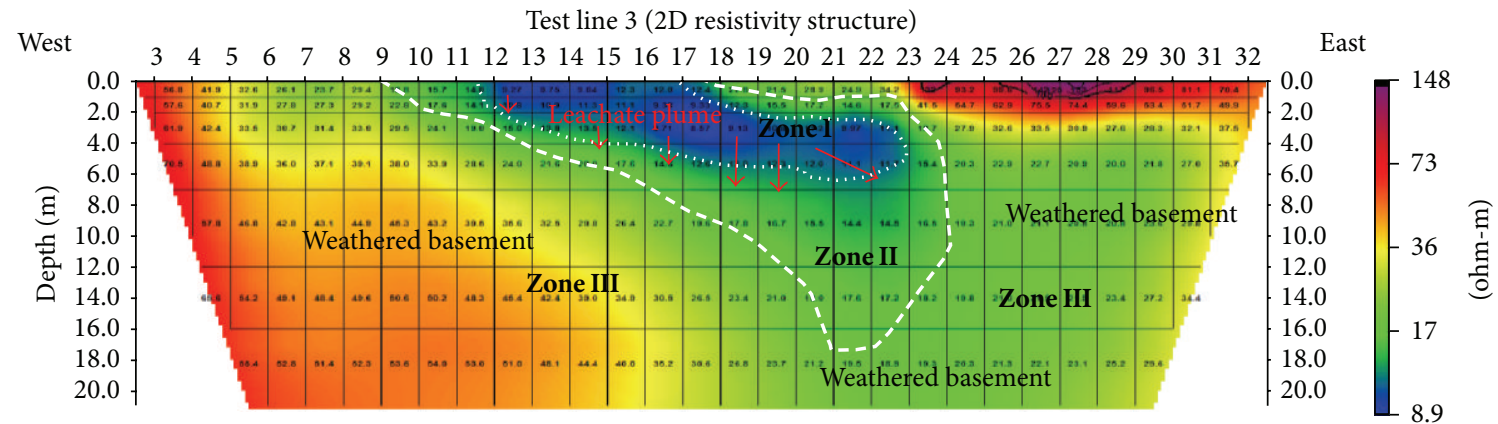

(c)

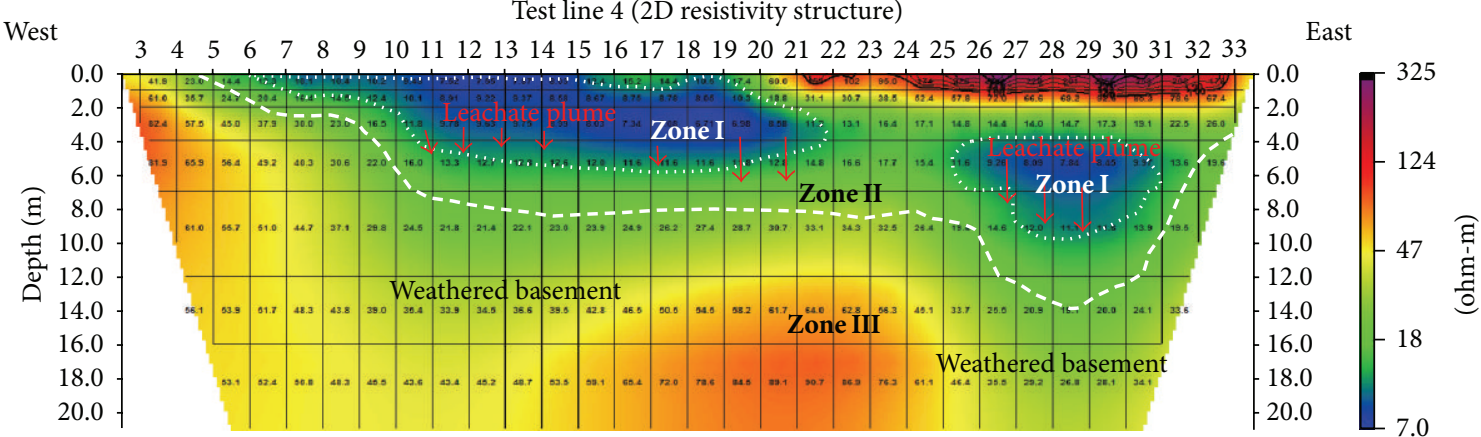

(d)

Figure 4: (a) The 2D imaging along profile 1. (b) The 2D imaging along profile 2. (c) The 2D imaging along profile 3. (d) The 2D imaging along profile 4 . 
TABLE 3

\begin{tabular}{|c|c|c|c|c|c|c|c|}
\hline \multirow{3}{*}{ Parameters } & \multirow{3}{*}{ Unit } & \multicolumn{5}{|c|}{ Hand dug well } & \multirow{3}{*}{ WHO standard (2004) } \\
\hline & & $\mathrm{M}$ & $\mathrm{N}$ & $\mathrm{A}$ & $\mathrm{B}$ & $\mathrm{C}$ & \\
\hline & & West & West & East & East & East & \\
\hline Turbidity & NTU & 1.00 & 1.00 & 1.53 & 4.56 & 4.56 & $1-5$ \\
\hline TSS & $\mathrm{Mg} / \mathrm{L}$ & 10 & 10 & 30 & 30 & 40 & \\
\hline TS & $\mathrm{Mg} / \mathrm{L}$ & 120 & 40 & 1130 & 2530 & 2540 & \\
\hline $\mathrm{PH}$ & $\mathrm{pH}$ unit & 6.95 & 6.85 & 7.15 & 7.55 & 6.95 & $6.6-8.5$ \\
\hline Conductivity & $\mathrm{US} / \mathrm{cm}$ & 175 & 49 & 1655 & 3470 & 3480 & 1500 \\
\hline TDS & $\mathrm{Mg} / \mathrm{L}$ & 110 & 30 & 1100 & 2500 & 2500 & $500-1000$ \\
\hline $\mathrm{Ca}^{2+}$ & $\mathrm{Mg} / \mathrm{L}$ & 3.13 & 2.40 & 13.47 & 65.13 & 69.56 & 75-200 \\
\hline $\mathrm{Mg}^{2+}$ & $\mathrm{Mg} / \mathrm{L}$ & 2.75 & 2.75 & 18.98 & 17.70 & 18.75 & $50-150$ \\
\hline $\mathrm{Na}^{+}$ & $\mathrm{Mg} / \mathrm{L}$ & 8.50 & 14.01 & 84.30 & 222.50 & 177.70 & $20-200$ \\
\hline $\mathrm{K}^{+}$ & $\mathrm{Mg} / \mathrm{L}$ & 1.56 & 1.06 & 143.9 & 261.9 & 251.00 & \\
\hline $\mathrm{No}_{3}{ }^{-}$ & $\mathrm{Mg} / \mathrm{L}$ & 1.00 & 1.00 & 58.00 & 64.00 & 68.00 & $45-50$ \\
\hline
\end{tabular}

presumed to be the true resistivity of the clayey overburden. The profile is as shown in Figure 4(b).

Profile 3. This is $50 \mathrm{~m}$ away from profile 2 towards the north of the dumpsite and also runs in an east-west direction (Figure 4(c)). Very low resistivity zone (blue colour) with resistivity value (between $9.7 \Omega$-m to $13.8 \Omega$-m) was isolated at the surface and to deeper depths between $2 \mathrm{~m}$ and $6 \mathrm{~m}$ at the middle of the profile between stations 11.5 and 22. It forms an oblong shaped structure pointing towards the east. This is the contaminant leachate plume mixed with decomposing waste and is contaminating the surrounding soil; this zone is classified as very high impact zone, this zone is of moderate depths under this profile.

This second zone is a zone of resistivity values ranging between $14 \Omega-\mathrm{m}$ and $25 \Omega-\mathrm{m}$. It occurs to the eastern section of the profile with depths ranging between $4 \mathrm{~m}$ and $20 \mathrm{~m}$; this zone is classified as high impact zone. The leachate plume contaminant is gradually reaching this zone.

The third zone is the zone with resistivity value varying between $25 \Omega-\mathrm{m}$ and $35 \Omega-\mathrm{m}$; this zone is classified as a low impact zone.

The fourth zone is a zone of no impact. The zone is also towards the west of the profile. The resistivity values of this zone are greater than $35 \Omega-\mathrm{m}$; this value is believed to be the true resistivity of the clayey overburden. However the area extent of impact is wider than the two previous profiles. The profile is as shown in Figure 4(c).

Profile 4. It is $50 \mathrm{~m}$ away from profile 3 towards the north. It also runs in an east-west direction (Figure 4(d)). A high resistivity zone occurs between stations 21 and 33 at relatively shallow depth of $2 \mathrm{~m}$. This zone was not impacted with the leachate plume.

Two very low resistivity zones (blue colour) (7.84 $\Omega$-m to $13.1 \Omega-\mathrm{m}$ ) were isolated under this profile. The first one is an oblong shaped anomaly occurring from the surface between stations 7 and 21 . The average depth to its base is about $6 \mathrm{~m}$. The second contaminant plume delineated occurs between stations 26 and 31. It is an oblate shaped anomaly.
Its depth of occurrence lies between $4 \mathrm{~m}$ and $10 \mathrm{~m}$. This is the contaminant leachate plume mixed with decomposing waste and contaminating the surrounding soil; this zone is classified as very high impact zone.

The second zone is a zone of moderately low resistivity values ranging between $12 \Omega-\mathrm{m}$ and $25 \Omega-\mathrm{m}$. It occurs between stations 4 and 32 with depth to its base ranging between $2 \mathrm{~m}$ and $18 \mathrm{~m}$; this zone is classified as high impact zone, because of the low resistivity values.

The third zone is the zone with resistivity value varying between $25 \Omega-\mathrm{m}$ and $35 \Omega-\mathrm{m}$, the zone is classified as a low impact zone implying that the leachate contaminant is just trying to approach this zone; therefore, its concentration within this zone is very low.

The last zone is a zone of no impact. The resistivity values of this zone are greater than $35 \Omega$-m; this value is believed to be the true resistivity of the clayey overburden. This profile is also a highly impacted profile as shown in Figure 4(d). This supports the notion that the leachate plume is migrating towards the north as well. Table 2 shows the summary.

\section{Geochemical Analysis}

Water samples were taken from five hand dug wells around the dumpsite. Two of the wells are on the western side of the site while the remaining three are from the eastern side where we presumed that the contaminant is migrating towards. The geochemical analysis of the groundwater samples reveals very high total dissolved solids (TDS), very high conductivity, and very high nitrate ions for the three wells towards the east. The average value gotten for TDS is $2033 \mathrm{mg} / \mathrm{L}$, conductivity is $2868 \mathrm{mg} / \mathrm{L}$, and nitrate ion is $63 \mathrm{mg} / \mathrm{L}$. These values are above the World Health Organization (WHO) permissible limits for potable water. Table 3 shows the analysis.

\section{Conclusion}

The results of $2 \mathrm{D}$ electrical resistivity imaging and the geochemical analysis of the groundwater samples show that the dumpsite had generated contaminant plumes and is 
migrating actively. It has low resistivity value ranging between $4 \mathrm{ohm}-\mathrm{m}$ and $13.8 \mathrm{ohm}-\mathrm{m}$, which signifies a conducting fluid. The geochemical analysis of the water samples corroborated this assertion by showing high TDS and high conductivity. We believe that the leachate generated from this dumpsite is impacting the soil and subsequently impacting the groundwater flowing through the soil as well. These high values recorded for the parameters mentioned in Table 3 and the nitrate ion concentration shows the leachate generated from this dumpsite pose health challenges to the inhabitants of this area especially the ones living towards the east. The large width of the contaminant plume experienced in the northern and eastern directions is primarily due to groundwater flow. The plume had reached a considerable depth towards the east.

\section{Conflict of Interests}

The authors declare that there is no conflict of interests regarding the publication of this paper.

\section{Acknowledgments}

The authors sincerely appreciate the management and staff of Dasamol Georesource Company for providing the data for this work. They also thank Ogunniyi Rotimi, Akinfolarin Abiodun, and Awotunde Wale for assisting with the data collection.

\section{References}

[1] C. N. Ehirim, J. O. Ebeniro, and O. P. Olanegan, "A geophysical investigation of solid waste landfill using 2-D resistivity imaging and vertical electrical sounding methods in Port Harcourt municipality, Rivers State, Nigeria," The Pacific Journal of Science and Technology, vol. 10, no. 2, pp. 604-613, 2009.

[2] O. Egwebe, C. O. Aigbogun, and S. O. Ifedili, "Geo-electrical evaluation of waste dump sites at Warri and its environ, Delta State, Nigeria," Journal of Applied Sciences and Environmental Management, vol. 11, no. 2, pp. 61-64, 2007.

[3] H. Rosqvist, T. Dahlin, A. Fourie, L. Rohrs, A. Bengtsson, and M. Larsson, "Mapping of leachate plumes at two landfill sites in South Africa using geoelectrical imaging techniques," in Proceedings of the 9th International Waste Management and Landfill Symposium, pp. 1-10, Cagliari, Italy, October 2003.

[4] O. J. Olaniran, "Evidence of climatic change in Nigeria based on annual series of rainfall of different daily amounts, 1919-1985," Climatic Change, vol. 19, no. 3, pp. 319-340, 1991.

[5] D. S. MacFarlane, J. A. Cherry, R. W. Gillham, and E. A. Sudicky, "Migration of contaminants in groundwater at a landfill: a case study. 1. Groundwater flow and plume delineation," Journal of Hydrology, vol. 63, no. 1-2, pp. 1-29, 1983.

[6] Becker and J. Carol, "Hydrogeology and leachate plume delineation at a closed municipal landfill, Norman, Oklahoma," U.S Geological Survey Water Resources Investigations Report 014168, 2002.

[7] S. I. Jegede, B. Osazuwa, O. Ujuanbi, and C. C. Chiemeke, "2-D electrical imaging survey for situation assessment of leachate plume migration at two waste disposal sites in the Zaria basement complex," Advances in Applied Science Research, vol. 2, no. 6, pp. 1-8, 2011.
[8] P. J. Carpenter and K. R. Reddy, "Refuse conductivity variations following leachate injection in a bioreactor landfill cell: modeling EM results and comparison with well logs," in Proceedings of the Symposium on the Application of Geophysics to Engineering and Environmental Problems (SAGEEP '11), vol. 24, p. 76, April 2011.

[9] M. H. Loke, Electrical Imaging Survey Environment and Engineering Studies: A Practical Guide to 2-D and 3D Surveys, Geometrics, San Jose, Calif, USA, 1999.

[10] C. Bernstone, T. Dahlin, T. Ohlsson, and W. Hogland, "DCresistivity mapping of internal landfill structures: two preexcavation surveys," Environmental Geology, vol. 39, no. 3-4, pp. 360-371, 2000.

[11] E. Orellana and H. M. Mooney, Master Tables and Curves for Vertical Electrical Sounding over Layered Structures, Interciencia, Madrid, Spain, 1966.

[12] A. I. Olayinka and U. Yaramanci, "Choice of the best model in 2-D geoelectrical imaging: case study from a waste dump site," European Journal of Environmental and Engineering Geophysics, vol. 3, no. 3, pp. 221-244, 1999. 

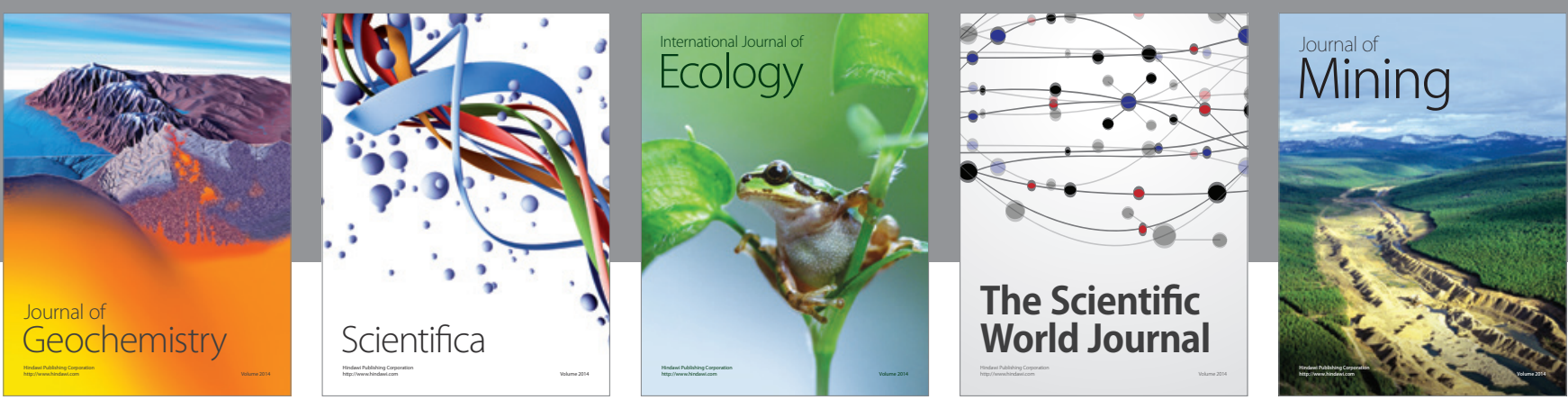

The Scientific World Journal
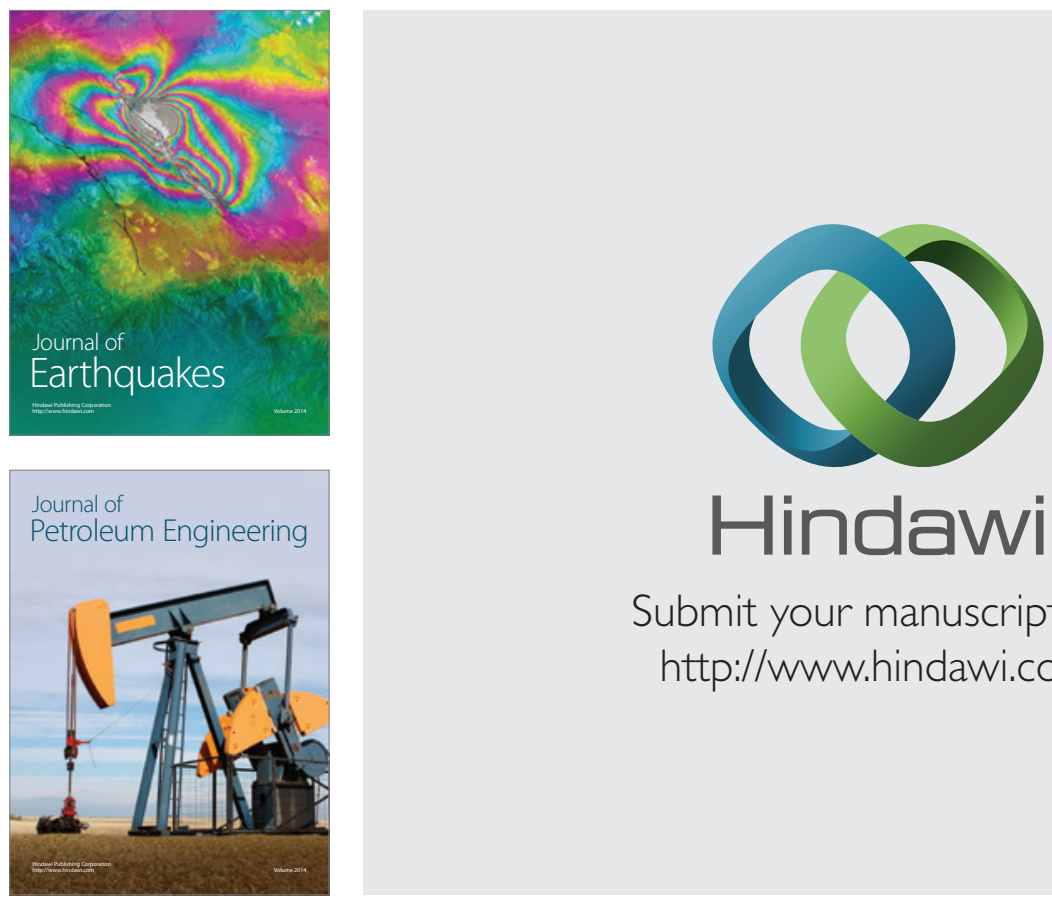

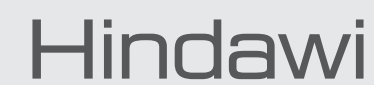

Submit your manuscripts at

http://www.hindawi.com
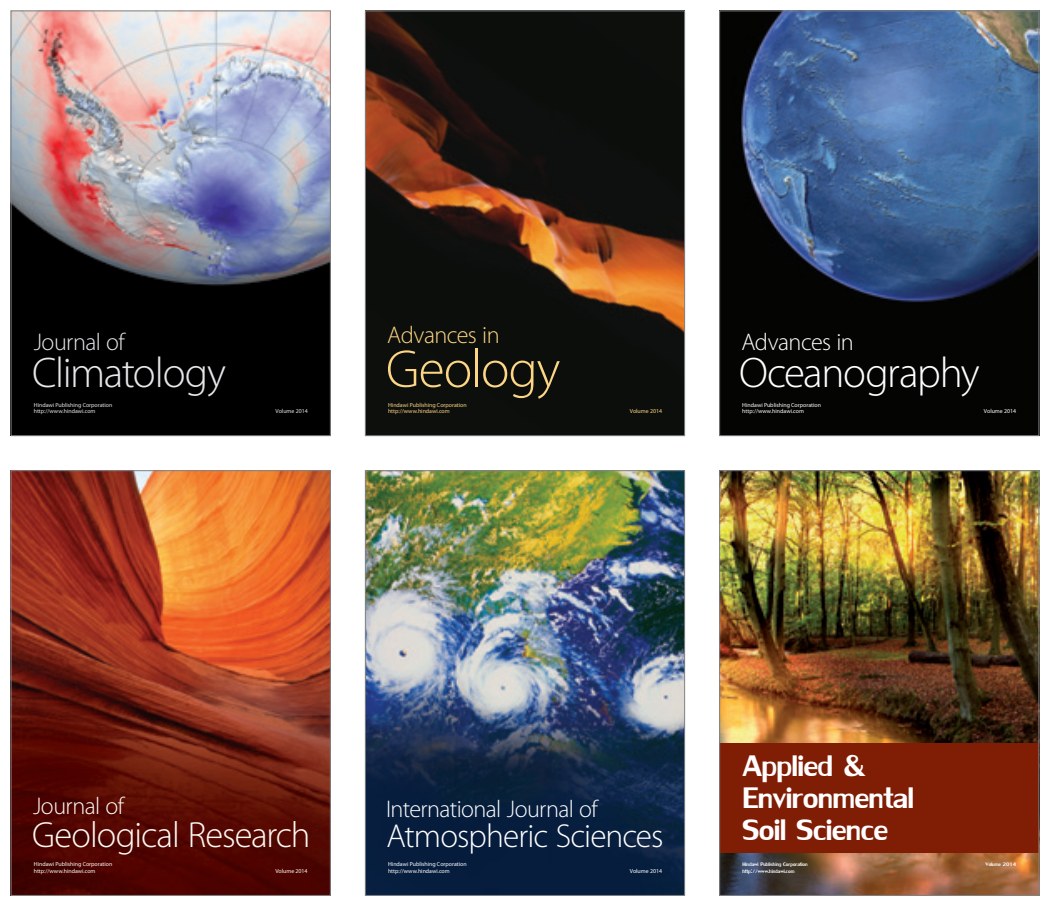
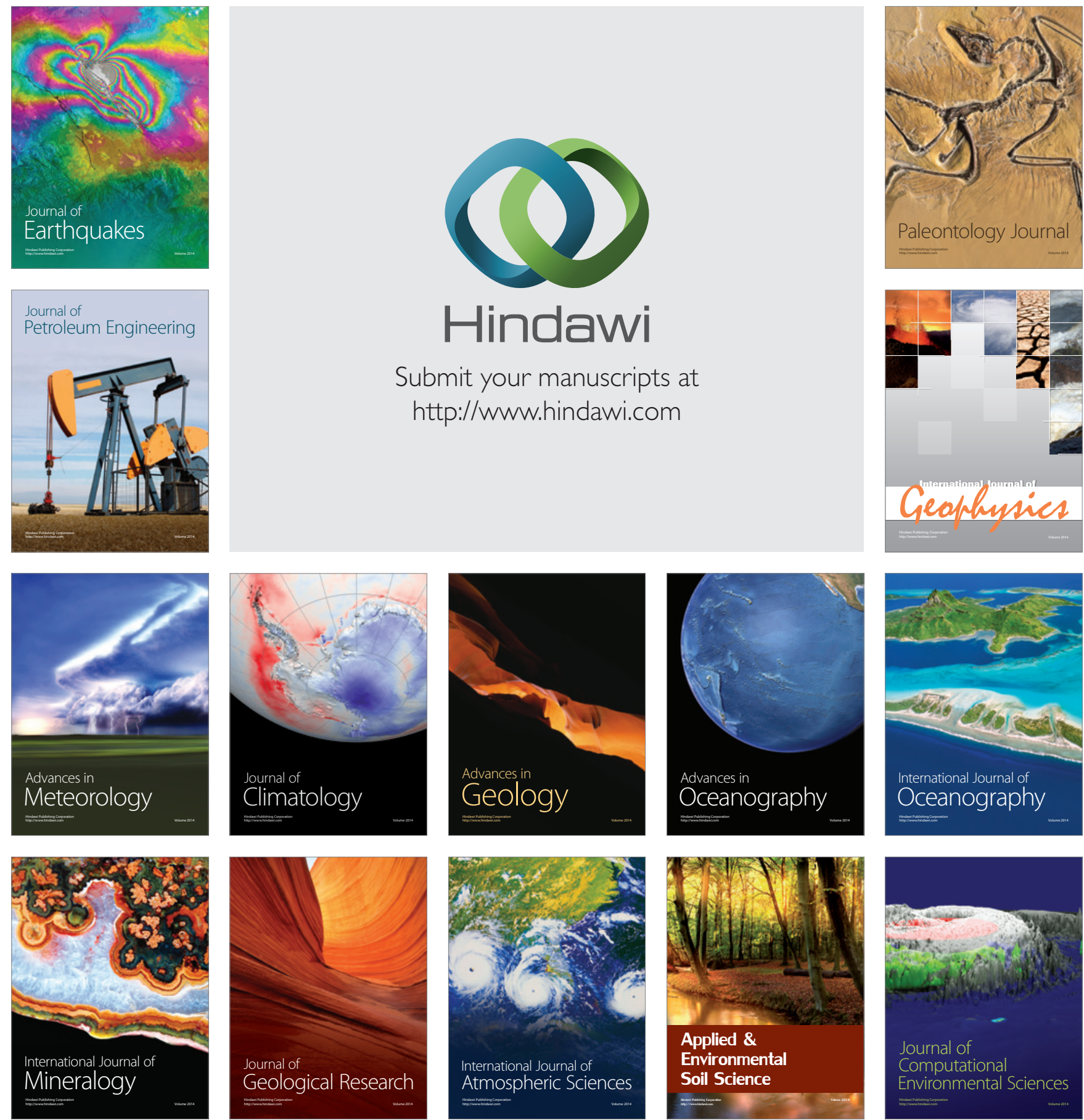